\title{
Past, present and future of la Albufera of Valencia Natural Park
}

\author{
J. M. Soria \\ Departament de Microbiologia i Ecologia. Facultat de Ciències Biològiques. Universitat de València. \\ 46100 - Burjassot (Valencia). Spain. E-mail: juan.soria@uv.es
}

\begin{abstract}
The Albufera of Valencia is a highly eutrophied coastal lagoon. Its ecological importance is recognised internationally. The complexity of the system functioning, as well as its location in a highly populated environment (marshland surrounded by rice crops), makes difficult the recovery of the system, in spite of the works carried out by the different organisms. The Department of Environment is developing an integral study to determine which are the necessary performances in order to make possible the sustainable development of the area as well as the conservation of the ecosystem. This and other studies aim to determine the current state of the problem and the necessary main works to solve it. With the current information, and keeping in mind the result of the last evaluation, it is necessary to contribute a bigger volume of water of good quality to the lagoon. This water will maintain the general quality of the lagoon and also, the arrival of the polluting substances will be eliminated.
\end{abstract}

Keywords: Albufera of Valencia, Water management, Eutrophication, Coastal lagoons

\section{RESUMEN}

La Albufera de Valencia es una laguna costera altamente eutrofizada. Su importancia ecológica está reconocida internacionalmente. La complejidad del funcionamiento de este sistema, unida a que está ubicada en un entorno altamente poblado y rodeada de un marjal dedicado al cultivo del arroz, hace dificil la recuperación del mismo a pesar de las acciones en este sentido que realizan los diferentes organismos que tienen competencias sobre la Albufera y su entorno. Para determinar cuáles son las actuaciones necesarias para mantener el desarrollo sostenible de la zona y procurar la mejora del ecosistema, el Ministerio de Medio Ambiente ha encargado recientemente un estudio integral. El fin de este y otros estudios es llegar a conocer el estado actual del problema y sugerir las acciones necesarias para solventarlo. Con la información que se tiene en la actualidad y teniendo en cuenta el resultado de la última evaluación se concluye que es necesario que a la Albufera se le aporte un mayor volumen de agua de buena calidad que será quien mantenga la calidad general del lago y además, se elimine la llegada de las sustancias contaminantes.

Palabras clave: Albufera de Valencia, Gestión del agua, Eutrofización, Lagunas costeras

\section{INTRODUCTION}

La Albufera of Valencia is a coastal lagoon placed in the Mediterranean coast line south from Valencia about 7.5 kilometres from Turia river mouth. The lagoon is surrounded by marshlands mainly devoted to rice crops and orchards, scattered country houses and coast line resorts, conforming a stunningly beautiful landscape, under human pressure. The marshland, the lagoon and the sandy dunes that detach the lagoon from the Mediterranean Sea were awarded the category of Natural Park by the Valencian Autonomous Government by decree 89/1986. Since 1990 this natural park has been included among the "international important wetlands" record established by the Ramsar agreement dated February 1971. It was also recognized as a special area for bird protection (ZEPA) since 1991. The set of small subterranean water springs or "ullals" had been protected by decree 96/1995 that gave green light to the "Natural resources management plan" of La Albufera hydrographical basin. This wetland shows a very knotty state, where several interests interact: agriculture, fishing and hunting, the town planning construction, neighbouring villages industrial plans, the tourism pressure, recreational or conservati- 
ves interests, making up a not yet solved problem. The maintenance of natural areas (landscape sites, reserve areas) and water management policy are very controversial matters, as it is currently happening in La Albufera.

The goal of this paper is to describe the problem, departing from its roots and summing up the current intervention proposals to improve its situation.

\section{METHODS}

The data about the past and present limnological estate have been drawn both from existing bibliography and studies carried out by the author. The on-coming plans for La Albufera the work made by TYPSA for the Confederación Hidrográfica del Júcar (River Júcar Basin Authority) have also been considered (TYPSA, 2005).

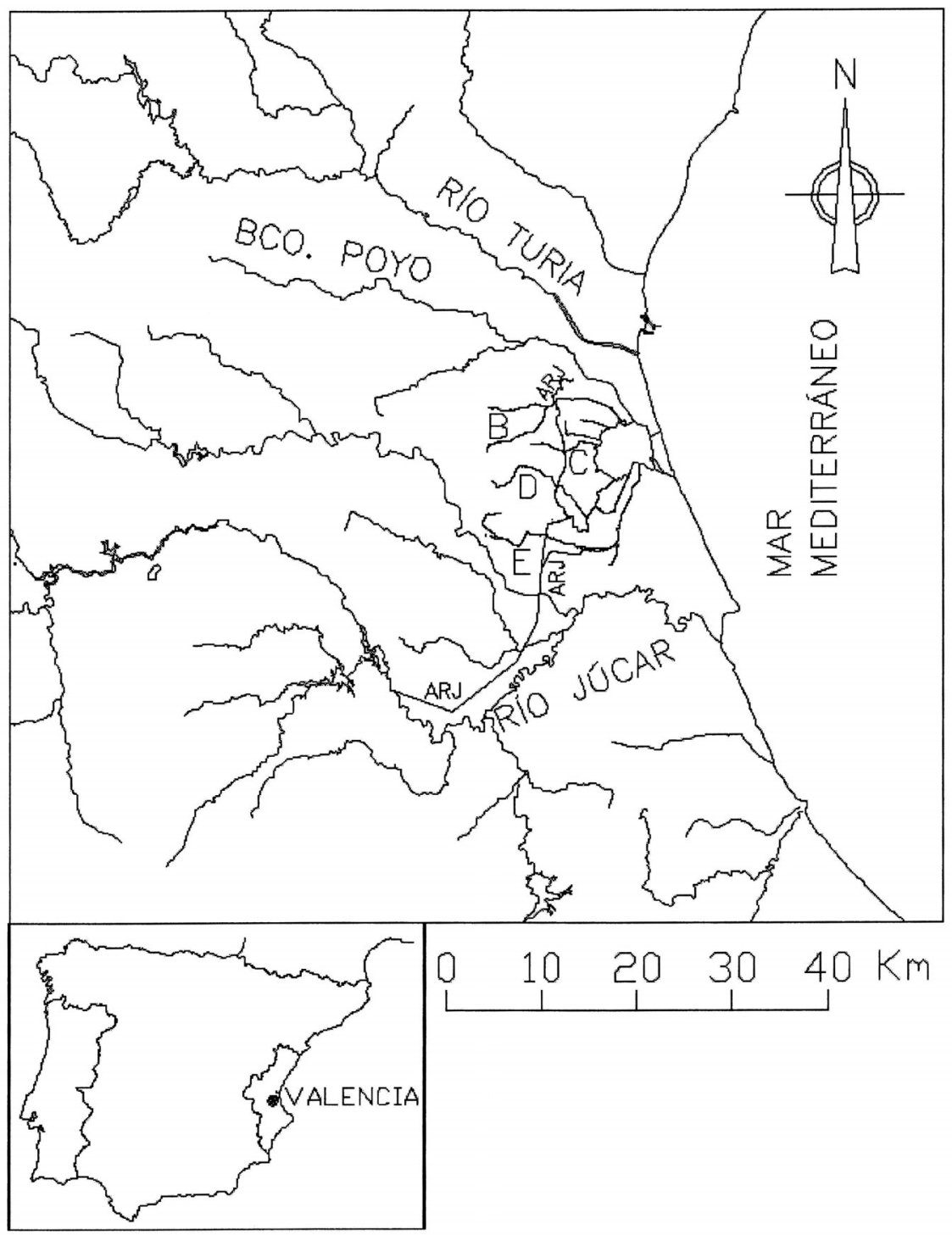

Figure 1. The Albufera of Valencia Lagoon and the rivers and gullies in the surrounding area. They are indicated the Turia and Jucar river, the Poyo gully and the minor gullies: B, Picassent - Beniparrell; C, Hondo - Tramusser; D. Berenguera y E, Agua Alginet. ARJ indicates the way of the Royal Channel of the Jucar River. Croquis de La Albufera de Valencia y los cauces naturales en su entorno y su cuenca hidrográfica. Se indican el río Turia y Júcar, el Barranco de Poyo y los barrancos menores: B, Picassent - Beniparrell; C, Hondo-Tramusser; D. Berenguera y E, Agua-Alginet. ARJ indica el trazado de la Acequia Real del Júcar. 


\section{The Albufera morphometry}

The most recent morphometric (TYPSA, 2005) and hydrologic parameters of La Albufera, are the following:

Average depth: $0.9 \mathrm{~m}$ a.s.1. Lagoon perimeter: $23.9 \mathrm{~km}$

Surface of the free water sheet: $22.3 \mathrm{~km}^{2}$

Surface covered by vegetation. $2.0 \mathrm{~km}^{2}$

Water volume: (minimal at 0.0 masl) $17.2 \mathrm{hm}^{3}$

Water volume (highest ordinary) $27.0 \mathrm{hm}^{3}$

Basin area: $917 \mathrm{~km}^{2}$

Natural Park area: $211.2 \mathrm{~km}^{2}$

Water contribution volume (2004): $170 \mathrm{hm}^{3}$

Average water renewal rate (2004): 7.39 times= 49, 5 days.

\section{THE HYDRAULIC OPERATION}

Five natural streams flow into La Albufera lagoon: Poyo-Torrent-Massanassa Gully, Picassent Beniparrell Gully, Hondo - Tramusser Gully, Berenguera Gully and Agua - Alginet Gully (Fig. 1). Before the expansion of the irrigation in the surrounding shores (until the construction of the second phase of Acequia Real del Júcar and Acequia Mayor in Sueca in XVIII century) the surface waters flowing to the lagoon were scarce. The rivers Turia and Jucar, which were originating the system, did not contribute on an steady basis to its hydric balance, because they only flew into the lagoon in case of flood. La Albufera was receiving the water which was left from the irrigation channels of Favara and Oro (coming from Turia river)

The sea connection of La Albufera has been controlled by man in the last centuries throughout the building of artificial channels called "golas". Prior to XVIII century the lagoon connected with the sea by means of just one 200-m wide "gola", allowing water flowing in both directions depending on the weather conditions. The water was more or less salty because its broad and scarcely controlled sea channel that allowed the mixing of sea and continental water. This system made possible the fishing use and yielded an important salt crop as well. The lagoon level fluctuations began to be modified in order to allow for bigger catches. For such a purpose the channel would be opened or closed depending on the fish reproductive cycles. By then, rice production was still scant (Rosselló, 1995).

Later (XIX and XX centuries) the connections between La Albufera and the sea began to increase. New "golas" were ditched, up to the three which are existing nowadays (Perelló, Perellonet and Pujol Nou). Improvements in the water circulation was the answer to the ancient solid matter sedimentation problem, an expression of the materials dragged by flowing water to the lagoon. That could entail a natural barrage on the water exit to the sea causing catastrophic consequences on the neighbouring crops (property of land owners and nobility). This, together with the need to regulate and manage the flooding periods, brought in the need of taking into consideration the problem of drainage and the widening of the sea connections.

Irrigation development increased drastically the incoming of surface water. The expansion of irrigation in the lowlands of Valencia, from Turia river, Jucar river, Acequia Real and Sueca and Cullera Main irrigation channels derived to the lagoon a high amount of fresh water which before flew into the sea, a tendency that has been increasing in the last years. The most representative civil work was the second phase of the "Acequia Real del Júcar" started out in 1767 by the Duke of Hijar and Señor of Sollana for the purpose of irrigating his own land and those of royal property which were at the borders surrounding the lagoon. This channel allowed the transformation on unirrigated areas (those spanning between Magro river and Poyo gully) into irrigated land. New channels were opened along XVIII and XIX centuries in La Ribera Baja (Acequia Mayor of Sueca in 1798) and the Huerta of Valencia (extension of Favara irrigation channels and that from Francos and Marjales towards the lagoon). In all the number of streams flowing into La Albufera multiplied its number by ten in slightly more than a century.

As a consequence, agrarian colonisation increased during the XVIII century the lagoon, 
and lead to the expansion of the rice crops. This supposed a spectacular increase in the water intake, the reduction of the lagoon dimensions and the opening of new sea exits. One of the main worries of those who have been in charge of the lagoon management has been the functioning of its hydrologic system, aiming to control the water level needed in the rice crops.

The hydrologic management model is reflected in the two entities that embody the conflict between both historical activities linked to La Albufera: fishing and agriculture. On one hand the "Comú de Pescadores de la ciudad de Valencia" put forward the fishing activity as a mean to take advantage of the natural resources, confronting it to the farmer's aggressions. On the other hand, the "Junta de Desagüe" which took over competences on the hydrological system management and, up to the present day, still controls the "golas" without any environmental sensibility.

Nowadays fresh water flows into the lagoon through 64 spots, of which 5 are mouths of its hydrographical basin and the rest are channels which flow into La Albufera, mainly carrying irrigation waters from the fields, as well as urban and industrial outflows. The irrigation waters coming from the Turia system are derived through a channel network from Quart, Mislata, Favara and Oro irrigation channels and its water quality is poor. This is particularly true for the two last ones, which stem from the highly polluted Repartiment reservoir, that receives untreated industrial wastes coming from Paterna and the industrial estate "Fuente del Jarro". The irrigation waters from the Acequia Real are more relevant and of better quality. Since water contribution to the whole system has been linked to agriculture, the contribution coming from the rivers has been decreasing throughout the last twenty years due to a better water management. The volume of water contribution has been of $280 \mathrm{hm}^{3}$ in 1988 and $170 \mathrm{hm}^{3}$ in 2004. During the severe drought of year 1995 the volume was just 120 $\mathrm{hm}^{3}$ (Soria et al., 2005), being the minimum flow fixed by the Jucar Basin Hydric Management Plan (Plan Hidrológico del Júcar) (CHJ, 1997) of $100 \mathrm{hm}^{3}$.
Another important aspect when studying the hydrological changes produced in La Albufera of Valencia is the urban and industrial development. Both urban and industrial development have been characterized by accelerated growth, producing a chaotic situation that impairs its control and spatial planning. This constitutes a severe problem for the lagoon, because of the high polluting capability of these industries and the lack of wastewater treatment plants. Altogether, 428123 inhabitants and 206 industries were censed in 1989, which join an unknown number of sources which are pouring untreated toxic waste to municipal sewers (Soria and Vicente, 2002).

\section{WATER QUALITY}

La Albufera is a coastal lagoon characterised by more or less muddy waters, depending on the suspended matter it receives. Due to its shallowness, it had an extraordinary development of emerging aquatic plants; air photographs (1956) and contemporary film documentaries (Anwander, 1957) showed that vegetation covered the largest part of the lagoon surface. This vegetation disappeared in the so called channels or paths used by the boats to sail from port to port. Water quality in La Albufera and its surroundings impaired since the 40's, with a severe turndown from the 60's on. In the 70's aquatic plants had already disappeared, just remaining the reed in the shores. Main causes of this were both urban development and the industrialization of the basin and its surroundings.

Between 1970 and 1980 the lagoon shifted from an oligotrophic to an hypertrophic state (Vicente and Miracle, 1992). Nowadays it is an hypertrophic system caused by the excessive intakes of allocthonous organic material and inorganic nutrients, mainly nitrogen and phosphorus compounds (Soria et al., 2002). This causes the overwhelming growing of cyanobacteria all throughout the year (Villena and Romo, 2003). The temporal rain distribution in its basin and the irrigation contributions have effects on the water conductivity (Soria et al., 2000, 
Table 1. Limnological variables before (1986-88) and after (1997-2000) sewage diversion from Albufera of Valencia lagoon. Probability values (P) refer to Wilcoxon's test on monthly means (modified from ROMO et al. 2005).Variables limnológicas antes (1986-88) y después (1997-2000) de la disminución de los vertidos a la Albufera de Valencia. Los valores de probabilidad P se refieren al test realizado sobre las medias mensuales de Wilcoxon (modificado de ROMO et al. 2005).

\begin{tabular}{lccc}
\hline Variable & $\mathbf{1 9 8 6 - 8 8}$ & $\mathbf{1 9 9 7 - 2 0 0 0}$ & P Wilcoxon \\
\hline Conductivity $\left(\mu \mathrm{S} \mathrm{cm}^{-1}\right)$ & $1784 \pm 389$ & $1878 \pm 306$ & 0.67 \\
Average annual temperature $\left({ }^{\circ} \mathrm{C}\right)$ & $18.7 \pm 6.9$ & $19.4 \pm 6.2$ & 0.21 \\
pH & $8.8 \pm 0.4$ & $9.0 \pm 0.4$ & 0.05 \\
Secchi disc depth $(\mathrm{m})$ & $0.21 \pm 0.08$ & $0.27 \pm 0.15$ & 0.59 \\
Nitrate $\left(\mathrm{mg} \mathrm{N} \mathrm{1}^{-1}\right)$ & $0.94 \pm 0.61$ & $0.97 \pm 1.00$ & 0.75 \\
Ammonia $\left(\mathrm{mg} \mathrm{N}^{-1}\right)$ & $0.99 \pm 1.66$ & $0.81 \pm 0.49$ & 0.78 \\
Soluble Reactive Phosphorus $\left(\mathrm{mg} \mathrm{P} \mathrm{1}^{-1}\right)$ & $0.17 \pm 0.25$ & $<0.01$ & $<0.01$ \\
Total Phosphorus $\left(\mathrm{mg} \mathrm{P}^{-1}\right)$ & $0.49 \pm 0.2$ & $0.34 \pm 0.14$ & 0.03 \\
Chlorophyll $a\left(\mu \mathrm{g} \mathrm{l}^{-1}\right)$ & $269 \pm 68$ & $180 \pm 53$ & $<0.01$ \\
\hline
\end{tabular}

2005), but this is mainly affected by the water flow management through the opening and closing of the "golas" floodgates (Soria and Vicente, 2002). Finally, water quality is influenced by both the amount of nutrients and organic matter carried by several channels that produces the eutrophic estate of the system.

The substitution of rice crops by more profitable and intensive crops (orchards) are related to the water pollution used to irrigate the fields. These turned out to be true decantation reservoirs (Vicente and Miracle, 1992). The most serious outcome derived from the shift in crops has been the reduction of the marshland (wetland surrounding the lagoon shore) by means of drainage and filling works, thus shrinking the wetlands that confer La Albufera its value as Natural Park.

Generally speaking, agrarian transformation meant a highly negative drawback due to agrochemical pollution. Nowadays a better coexistence between agricultural activity and natural values preservation is meant. Therefore, in order to preserve rice crops (which are a cushion area against pollution), several grants have been issued aiming to decrease the pesticide pollution in the lagoon. Moreover, farmers are compensated for hypothetical damage in crops caused by protected birds (Las Provincias, 2004).

Erosion is another of the lagoon big issues, since it is fundamentally related to human activity. Different soil classes, forest practices and arsons set up the amount of actual eroded and erodable soil. Furthermore, waters in contributing channels carry on a high amount of anthropic sediments and eroded materials. So, all in all, this erosion means a big amount of material which is alien to the lagoon (Sanjaume et al., 1992).

La Albufera receives undepurated sewage waters from urban origin, together with those of water treatment plants. Moreover, dumping of highly polluted sewage through gutters occurs mainly under rainy weather. Nowadays, the West Main Sewer dumps sewage through its gutters even in times of dry weather (TYPSA, 2005), and its pumping devices show clear deficiencies (Soria, personal observation).

All these contributions have negatively contributed to the trophic quality of the lagoon in the last fifteen years (Romo et al., 2005). Although phosphorus concentration has decreased since the 80 's, nowadays it stands between 0.49 until $0.34 \mathrm{mg} \mathrm{P} \mathrm{l}^{-1}$; chlorophyll average stands between $269 \mu \mathrm{g} \mathrm{l}^{-1}$ until $180 \mu \mathrm{g} \mathrm{l}^{-1}$ (Table 1). During some clean phases it has gone under $10 \mu \mathrm{g}^{-1}$ for a few days only to restore, also in a short span of time, to the actual average values (Miracle \& Sahuquillo, 2002), which are clearly unacceptable to keep the ecosystem quality.

Due to the high phytoplankton growth, $\mathrm{pH}$ stands at very high levels, seldom below 8.5, being the most frequent values of 9.5 , even 10 . That raises the rate of a toxic ammonia compound in water in a very dangerous way -mainly for fish-(Blanco et al., 2003). It is not 
only that the $\mathrm{pH}$ contributes to the ammonia compounds balance, but also that high temperatures provoke a rise in the rate of non ionized ammonia in water. Moreover, fluctuations in the dissolved oxygen as a result of the high production make animals more sensible to its toxicity (Vicente \& Miracle, 1992). A further consequence of the high micro-algae concentration is the high amount of native organic matter, whose breakdown can not be completed in an aerobic way, so that, as well as producing nightly oxygen shortage in water it remains sedimented organic matter, part of which decomposes in an anaerobic way freeing $\mathrm{H}_{2} \mathrm{~S}$.

\section{BIODIVERSITY}

Phytoplankton population growth is well described by Villena \& Romo (2003a and 2003b). Its main characteristic is the presence of cyanobacteria and chroococcales along with diatoms and chlorophyta. Zooplankton production is very reduced, and the hardly edible phytoplankton is recycled mainly by detritic way. There has been a loss of plankton filtering species capable of regulating the phytoplankton concentration, and consequently also of water quality and transparency. There is a higher contribution of Rotifera nowadays (Oltra et al., 2001). Native fish fauna is composed mainly by sea mullet (Mugil cephallus), sharpnose mullet (Liza aurata), carps, silverside fish and pumpkinseed sunfish (Blanco et al., 2003).

In the middle 80 's $(1984,1987)$ "clear water phases" in which the phytoplankton population drastically decreases was observed by Miracle \& Sahuquillo (2002). During 10 to 20 days water appears less muddy and in some spots, the lagoon bottom can even be seen. This phenomenon is produced by a substitution of the usual cyanobacteria plankton by other micro algae (diatoms and others) and the outcome of filter-feeders like Daphnia magna, capable of a very efficient filtration upon the algae population. This period of clear waters is probably related with the flowing of clean waters coming from the rice fields drainage after its initial flooding in January -
February. The "clear water phase" does not show a regular pattern, either temporally or spatially in the lagoon. The clear phases are an evidence of the recovering capability of the whole system provided that the quality and quantity of water in the tributary channels improves.

Nowadays some 250 bird species find shelter in the park and around 100 of them also reproduce there. The most numerous group during winter are the anatidae, ranging from 40.000 to 60.000 individuals. Worth mentioning is the redcrested pochard (Netta rufina), which attains about 17.000 individuals. Other common anatidae are the mallard (Anas platyrhynchos), the pochard (Aythya ferina) and the shoveler (Anas clypeata). Smaller number of individuals are pintails (Anas acuta), wigeons (Anas Penelope) and teals (Anas crecca). Ardeidae, such as grey herons (Ardea cinerea) little egrets (Egretta garzetta) and cattle egrets (Bubulcus ibis), are common during the winter and during nestling time attract international attention due to the high number of nests in the area (more than 2500). Significantly, the nestling species in the area of La Albufera ranks among those in the "List of Wetlands of International Importance" following the numerical criteria issued by Ramsar for several bird species, according to Valencian Ornitology Society data (2005).

The lagoon fauna (both fish and benthic) have undergone modifications throughout the years, as a result of several actions taken upon the system. Eel and bass have shown sharp decreases, while others are now extinct, such as the endemic "samaruc" Valencia hispanica and "fartet" Aphanius iberus. Other fishes as the loach and the chub are possibly restricted to some channel areas (Blanco et al., 2003). Several endemic species among the invertebrates are now considered extinct: Dugastella valentina and Palaemonetes zariquieyi (known as "gambetes") and the bivalvia Unio turtoni valentinus ("petxinot"), which can only be found in protected areas (Dugastella valentina and Palaemonetes zariquieyi) and possibly in some irrigation ditches (Unio turtoni valentinus) (Sánchez, 1991).

The flora plays an important role within the Park structure, setting up the placement and 
diversity of both bird and fish species living there. Nonetheless in the last years flora diversity has decreased because of the rise of pollution and the building construction along the coast line. Flora biodiversity is now reduced to the presence of riparian in channels irrigation ditches and the lagoon shores: common reed, common cattail, yellow iris, and bulrush. The surface of the lagoon occupied by macrophytes has drastically reduced the former abundance of Myriophyllum, Chara, Ceratophyllum, Potamogeton and Nymphaea alba. Ranunculus aquatilis grows only in rice crops during the flooding period (Sánchez, 1991). Variety and abundance of "clean water" species in the future would be an expression for the wetland water quality improvement.

\section{ACTIONS TO BE TAKEN ACCORDING TO THE STUDY OF SUSTAINABLE DEVELOPMENT}

Some essential actions are planned in the near future in order to improve the ecosystem quality (TYPSA, 2005), aiming to obtain a sensible improvement in 15-20 years time (Phillips, 2005):

a) Water. The ideal volume of water flowing into the lagoon should be more than $200 \mathrm{Hm}^{3}$ of water of good quality (less than $0.1 \mathrm{mg} \mathrm{P}^{-1}$ phosphorus), in order to prevent euthrophication (Romo et al., 2004). This would mean that contributions to the lagoon should come directly from reservoir waters. This water could be distributed among the rice fields in an ascending way, thus reversing the current flow scheme, later on it could be derived to other basins for agricultural purposes. In this sense the option of sending the amount of water left towards the Vinalopó basin would be highly advisable. The spare waters should be then directed towards the sea.

b) Erosion. Lessening the erosion means taking actions such as the reforestation in the watershed, updating agricultural practices, arson control and clear actions leading to recover affected spots. c) Agricultural areas. It would be desirable to obtain higher economic profits derived from rice crops and other varieties, cutting off the fertilizer and pesticide pollution hazards at the same time, taking into account that waters left from the flooding could be used for other agricultural practices.

\section{CONCLUSION}

Regardless of the efforts carried out by National, Regional and Municipal administration to preserve and improve the environmental state of $\mathrm{La}$ Albufera, after 20 years of investment and struggle, the eutrophy of the system has been scarcely reduced. Main problem is the west park boundaries urbanization which has overwhelmed the existing infrastructures, plus the slow pace in taking up unavoidable actions and the inappropriate management of flowing waters. To all this we must add the reduction of clean waters contribution coming from irrigation.

The achievement of a desirable situation, between mesotrophic and oligotrophic, is only possible if good quality waters, needed to keep the environmental qualities, flow in. Also the arrival of polluting substances directly linked to eutrophy must be cut in short time. The seldom appearance of clear water phases during last years is a manifestation that improvement is possible.

\section{BIBLIOGRAPHY}

ANWANDER, CH. 1957. Entre el agua y el barro: Estampas de la Albufera de Valencia. Writted by Christian Anwander \& Alfredo Marquerie. Documental film performed by NODO. $16 \mathrm{~min}$.

BLANCO, S., S. ROMO, M. J. VILLENA \& S. MARTINEZ. 2003. Fish communities and food web interactions in some shallow Mediterranean lakes. Hydrobiologia, 506 (1-3): 473-480.

CHJ (Confederación Hidrográfica del Júcar). 1997. Plan Hidrológico del Júcar. Documento $n^{\circ} 2$. Normativa. (On line). Available in World Wide Web http://www.chj.es/web/pdf/NORMATIVA.pdf

LAS PROVINCIAS. 2004. Territorio sólo paga la mitad del daño causado por aves en arroz. En 
Albufera de Valencia (On line). 12 november 2004. Available in World Wide Web: http://www.albufera.com/portal/modules.php?na me $=$ News $\&$ file $=$ article $\&$ sid $=800$

MIRACLE, M. R. \& M. SAHUQUILLO. 2002. Changes of life-history traits and size in Daphnia magna during a lear-water phase in a hypertrophic lagoon (Albufera of Valencia, Spain). Verh. Internat. Verein. Limnol., 28: 1203 - 1208.

OLTRA, R., M. T. ALFONSO, M. SAHUQUILLO \& M. R. MIRACLE, 2001. Increase of rotifer diversity after sewage diversion in the hypertrophic lagoon, Albufera of Valencia, Spain. Hydrobiologia, 446/447: 213-220.

PERIS, T. 1991. La problemática génesis del Segundo tramo de la Acequia Real del Xúquer. Investigaciones Geográficas 9: (On line). Available in World Wide Web: http://www.cervantesvirtual.com/servlet/SirveObras/013716304556 15946322257/invg_11.pdf

PHILLIPS, G., A. NELLY, J. PITT, R. SANDERSON \& E. TAYLOR. 2005. The recovery of a very shallow eutrophic lake, 20 years after the control of effluent derived phosphorus. Freshwat. Biol., 50 (10): 1628-1638.

ROMO S., M. R. MIRACLE, M. J. VILLENA, J. RUEDA, C. FERRIOL \& E. VICENTE. 2004. Mesocosm experiments on nutrient and fish effects on shallow lake food webs in a Mediterranean climate. Freshwat. Biol., 49 (12): 1593-1607.

ROMO, S., VILLENA, M. J., SAHUQUILLO, M., SORIA, J. M., GIMENEZ, M., T. ALFONSO, E. VICENTE \& M. R. MIRACLE. 2005. Response of a shallow Mediterranean lake to nutrient diversion: does it follow similar patterns as in northern shallow lakes? Freshwat. Biol., 50 (10): 1706-1717.

ROSSELLÓ, V. M. 1995. L'Albufera de Valencia. Publicacions de.l'Abadia de Montserrat. 190 pp.

SANCHEZ, J. 1991. Plan Especial de protección del Parque Natural de la Albufera. Conselleria de
Medi Ambient. Generalitat Valenciana. 148 pp.

SANJAUME, E., F. SEGURA, M. J. LÓPEZ \& J. PARDO. 1992. Tasas de sedimentación en L'Albufera de València. Cuad. de Geogr., 51: 63-81.

SORIA, J. M., E. VICENTE \& M. R. MIRACLE. 2000. The influence of flash floods on the limnology of the Albufera of Valencia lagoon (Spain). Verh. Internat. Verein. Limnol., 27: 2232-2235

SORIA, J. M. y E. VICENTE. 2002. Estudio de los aportes hídricos al Parque Natural de la Albufera de Valencia. Limnetica, 21(1-2): 105-115.

SORIA, J. M., M. R. MIRACLE \& E. VICENTE. 2002. Relations between physico-chemical and biological variables in aquatic ecosystems of the Albufera Natural park (Valencia, Spain). Verh. Internat. Verein. Limnol., 28: 564-568

SORIA, J. M., M. SAHUQUILLO y M. R. MIRACLE. 2005. Relaciones entre las aportaciones a la zona regable del río Júcar y la conductividad de la Albufera de Valencia. Limnetica, 24 (1-2): 155-160.

SVO (Societat Valenciana Ornitología). 2005. Sitios de interés: La Albufera de Valencia. (On line). Available in World Wide Web: http://www.ctv.es/ USERS/miguel-peris/LaAlbufera.htm

TYPSA. 2005. Estudio para el desarrollo sostenible de l'Albufera de Valencia. Confederación Hidrográfica del Júcar. (On line). Available in World Wide Web: http://www.albufera.com.es.

VICENTE, E. \& M. R. MIRACLE. 1992. The coastal lagoon Albufera de Valencia: An ecosystem under stress. Limnetica, 8: 87-100.

VILLENA M. J. \& S. ROMO. 2003. Temporal changes of cyanobacteria in the largest coastal Spanish lake. Algological Studies. 109: 593-608.

VILLENA, M. J. \& S. ROMO. 2003. Changes in the phytoplankton of a shallow Mediterranean lagoon (Albufera of Valencia, Spain) after nutrient diversión. Hydrobiologia. 506: 281-287 